\title{
COEFFICIENT PROBLEMS FOR UNIFIED STARLIKE AND CONVEX CLASSES OF $m$-FOLD SYMMETRIC BI-UNIVALENT FUNCTIONS
}

\section{Zhenhan Tu and LiAngPeng Xiong}

Abstract. Let $\mathscr{T}_{m}$ denote the class of $m$-fold symmetric bi-univalent functions in the open unit disk. We obtain the coefficient bounds of $\left|a_{m+1}\right|$ and $\left|a_{2 m+1}\right|$ for functions in a new general subclass $\mathscr{C}_{m}^{h, p}(\alpha)$ of $\mathscr{T}_{m}$, where $h$ and $p$ are in Carathéodary class of functions. We investigate the initial Taylor-Maclaurin coefficients estimate problems associated with $\mathscr{C}_{m}^{h, p}(\alpha)$ also. Our conclusion improves some earlier related results.

Mathematics subject classification (2010): 30C45, 30C50.

Keywords and phrases: Convex functions, Faber polynomial expansion, starlike functions, TaylorMaclaurin coefficients inequalities, univalent functions.

\section{REFERENCES}

[1] M. Abramowitz, I. A. Stegun (Eds), Handbook of Mathematical Functions with Formulas, Graphs, and Mathematical Tables, National Bureau of Standards, Applied Mathematics Series 55, 9th printing, Washington, 1970.

[2] W. BuRnside, A rapidly convergent series for $\log (N$ !), Messenger Math. 46 (1917), 157-159.

[3] R. M. Ali, S. K. Lee, V. Ravichandran, S. Supramaniama, Coefficient estimates for biunivalent Ma-Minda starlike and convex functions, Appl. Math. Lett. 25 (2012), 344-351.

[4] H. Airault, A. Bouali, Differential calculus on the Faber polynomials, Bull. Sci. Math. 130 (2006), 179-222.

[5] H. Airault, J. Ren, An algebra of differential operators and generating functions on the set of univalent functions, Bull. Sci. Math. 126 (2002), 343-367.

[6] Ş. Altinkaya, S. YALÇIn, Faber polynomial coefficient bounds for a subclass of bi-univalent functions, Stud. Univ. Babeş-Bolyai Math. 61 (2016), 37-44.

[7] D. A. Brannan, J. G. Clunie, Aspects of contemporary complex analysis, in: Proc. NATO Advanced Study Institute, University of Durham, Durham, July 1-20, 1979.

[8] D. A. BRAnnan, T. S. TAHA, On some classes of bi-univalent functions, In: Mazhar SM, Hamoui A, Faour NS, editors, KFAS Proceedings Series, Vol. 3, Oxford, UK: Pergamon Press, 1988, pp. 53-60.

[9] S. Bulut, Coefficient estimates for a new subclass of analytic and bi-univalent functions defined by convolution, Math. Notes. Miskolc 17 (2016), 101-110.

[10] M. ÇaĞLar, E. Deniz, H. M. SRIVAStaVa, Second Hankel determinant for certain subclasses of bi-univalent functions, Turk. J. Math. 41 (2017), 694-706.

[11] P. L. Duren, Univalent Functions, Grundlehren der Mathematischen Wissenschaften, Vol. 259, Berlin, Germany: Springer, 1983.

[12] E. DENIZ, M. ÇAĞLAR, H. ORHAn, Second Hankel determinant for bi-starlike and bi-convex functions of order $\beta$, Appl. Math. Comput. 271 (2015), 301-307.

[13] E. DENIZ, Certain subclasses of bi-univalent functions satisfying subordinate conditions, J. Class. Anal. 2 (2013), 49-60.

[14] S. S. EKER, Coefficient bounds for subclasses of m-fold symmetric bi-univalent functions, Turk. J. Math. 40 (2016), 641-646.

[15] B. A. Frasin, M. K. Aouf, New subclasses of bi-univalent functions, Appl. Math. Lett. 24 (2011), $1569-1573$.

[16] G. FABER, Uber polynomische Entwickelungen, Math. Ann. 57 (1903), 389-408. 
[17] S. G. HAMIDI, J. M. JAHANGIRI, Unpredictability of the coefficients of m-fold symmetric bi-starlike functions, Int. J. Math. 25 (2014), 1-8.

[18] M. JAhANGIRI, On the coefficients of powers of a class of Bazilevic functions, Indian J. Pure Appl. Math. 17 (1986), 1140-1144.

[19] A. W. Kedzierawski, Some remarks on bi-univalent functions, Ann. Univ. Mariae CurieSklodowska (Sect A) 39 (1985), 77-81.

[20] M. LewIn, On a coefficient problem for bi-univalent functions, Proc. Amer. Math. Soc. 18 (1967), 63-68.

[21] G. Murugusundaramoorthy, T. Janani, N. E. Cho, Coefficient estimates of Mocanu-type meromorphic bi-univalent functions of complex order, Proc. Jangjeon Math. Soc. 19 (2016), 691-700.

[22] E. Netanyahu, The minimal distance of the image boundary from the origin and the second coefficient of a univalent function in $|z|<1$, Arch. Rational Mech. Anal. 32 (1969), 100-112.

[23] H. ORHAN, N. MAGESH, V. K. BALAJI, Initial coefficient bounds for a general class of bi-univalent functions, Filomat, 29 (2015), 1259-1267.

[24] H. M. Srivastava, A. K. Mishra, P. Gochhayat, Certain subclasses of analytic and bi-univalent functions, Appl. Math. Lett. 23 (2010), 1188-1192.

[25] H. M. Srivastava, G. Murugusundaramoorthy, N. Magesh, Certain subclasses of biunivalent functions associated with the Hohlov operator, Global J. Math. Anal. 1 (2013), 67-73.

[26] H.M. SRivastava, S. Sivasubramanian, R. Sivakumar, Initial coefficient bounds for a subclass of $m$-fold symmetric bi-univalent functions, Tbilisi Math. J., 7 (2014), 1-10.

[27] H.M. SRivastava, D. BAnsal, Coefficient estimates for a subclass of analytic and bi-univalent functions, J. Egyptian Math. Soc., 23 (2015), 242-246.

[28] H.M. Srivastava, S.S. Eker, R.M. Ali, Coefficient Bounds for a Certain Class of Analytic and Bi-Univalent Functions, Filomat 29 (2015), 1839-1845.

[29] H.M. SRivastava, S. Gaboury, F. Ghanim, Initial coefficient estimates for some subclasses of $m$-Fold symmetric bi-univalent functions, Acta. Math. Sci., 36 (2016), 863-871.

[30] H.M. SRivastaVa, S. Gaboury, F. Ghanim, Coefficient estimates for some general subclasses of analytic and bi-univalent functions, Afrika Mat. 28 (2017), 693-706.

[31] H.M. SRivastava, S.S. EkeR, S.G. Hamidi, J.M. JAhAngiRi, Faber polynomial coefficient estimates for bi-Univalent Functions defined by the tremblay fractional derivative operator, Bull. Iran. Math. Soc. 44 (2018), 149-157.

[32] S. Sivasubramanian, R. SiVAKUmaR, Initial coefficient bound for $m$-fold symmetric bi- $\lambda$-convex functions, J. Math. Inequal., 10 (2016), 783-791.

[33] S. Sivasubramanian, R. Sivakumar, T. Bulboacă, T.N. Shanmugam, On the class of biunivalent functions, C. R. Acad. Sci. Paris., 352 (2014), 890-895.

[34] F.M. SAKAR, H.O. GÜNEY, Coefficient bounds for a new subclass of analytic bi-close-to-convex functions by making use of Faber polynomial expansion, Turk. J. Math., 41 (2017), 888-895.

[35] D.L. TAN, Coefficient estimates for bi-univalent functions, Chin. Ann. Math. (Ser A), 5 (1984), 559 568.

[36] L.P. XIOng, X.L. LiU, Some extensions of coefficient problems for bi-univalent ma-minda starlike and convex functions, Filomat, 29 (2015), 1645-1650.

[37] Q.H. XU, H.G. XIAO, H.M. SRIVASTAVA, A certain general subclass of analytic and bi- univalent functions and associated coefficient estimate problems, Appl. Math. Comput., 218 (2012), 1146111465.

[38] Q.H. Xu, Y.C. GUi, H.M. SRIVASTAVA, Coefficient estimates for a certain subclass of analytic and bi-univalent functions, Appl. Math. Lett., 25 (2012), 990-994. 